\title{
Home Based Enterprises and Parking on The Main Corporate Vocational School Denpasar
}

\author{
Master Programs of Architecture \\ Faculty of Engineering-Udayana University \\ Jimbaran \\ sayu.peny@gmail.com \\ Department of Architecture \\ Faculty of Engineering-Udayana University \\ Jimbaran \\ Department of Architecture \\ Faculty of Engineering-Udayana University \\ Jimbaran
}

Sayu Putu Peny Purnama Wati ${ }^{1}$, Ngakan Putu Sueca ${ }^{2}$, Ciptadi Trimarianto ${ }^{3}$

\begin{abstract}
The era of globalization as it is today is an era with technological advances that make it easier to obtain and obtain information. Easy internet access affects unlimited human desires. Many of these human desires form an increased lifestyle, to fulfill these desires many are looking for ways to earn additional income outside of their main job. One way out for people with middle to lower income is to create a business unit in their home or occupancy which is also called Home Based Enterprises or home-based businesses. This study seeks to analyze the characteristics of the hbes in the main corridor of Penatih Village, East Denpasar, which is a residential area. Changes in space that occur in the house, especially the telajak section into a business unit, cause a change in the behavior of the residents of the house and also the community of road users. This behavior has a significant impact on the development of the corridor in addition to decreasing the quality of the settlements to become less comfortable, the appearance of the building mismatch, traffic jams that make it unsafe to drive through the corridor due to economic activities carried out by residents and buyers, so parking space is needed. To accommodate vehicles that are parked to visit Hbes the goal is to create a beautiful, comfortable and safe environment.
\end{abstract}

Index Terms - home based enterprises, behavior setting, parking

\section{INTRODUCTION}

The house is one of the primary needs of humans and has various functions from self-development, carrying out social activities besides that the house is a place to make money and so on. According to Laquianb [1] states that today, the function of the house is not only used for household life but has other functions as a place of production, marketing, being an entertainment center, and also a place to be alone.
This activity is often found in residential areas, one of which is the Main Corridor of Penatih Village, Denpasar. According to the spatial regulations of the city of Denpasar, Penatih Urban Village functions as a center for agriculture and settlements, but along with the development of times and economic factors, many residents in the area in the Penatih sub-district, especially along the main corridor of the Penatih Village, have added the function of their houses into business land. When it is related to architectural developments where at this time residential lands have become narrow due to high land prices and also the influence of urbanization so that it has an effect on utilizing 
existing house land so that they are able to manage their business. This activity has increasingly led to changes in behavior towards the residents who live in the corridor and also changes in the behavior of road users. Changes in behavior where there are buying and selling activities between buyers and sellers, one of which is the buyer parking the vehicle on the side of the road which causes a decrease in the quality of settlements in the area. So that parking space is needed to accommodate visitor activities at each Hbes residential unit in the main corridor of Penatih Village, Denpasar

\section{RESEARCH METHODS}

The research method used is a qualitative method. Methods that emphasize in-depth understanding aspects of a problem rather than looking at the problem for generalization research. This research method prefers to use in-depth analysis techniques. Where this method will be used in the research explanation by describing existing empirical data about the residential function of houses that have shifted and added functions so that they are able to change spatial and find the results of analysis and conclusions of the problems encountered. Types and sources of data used are qualitative data in the form of observations of researchers in the field starting from the implementation of the research until the completion of the research carried out, of the urban spaces used in the city of East Denpasar. The observed city spaces include private and public spaces along the Main corridor of Penatih Village, Denpasar.

\section{THEORY}

\section{A. Home Base Enterprise}

Strassmann [2] defines home based enterprises as things that occur in or very close to homes rather than in buildings or commercial or industrial areas. Home-based companies or household businesses or unincorporated companies owned by households are distinguished from corporations and semi-corporations based on their legal status and the type they hold. Their activities are not established on the basis of a legal entity, separate independently from the household or household members they own and there is a confusion of differences between production activities and other activities of their owners [3]. The implementation of Hbes uses personal assets such as private residences, vehicles and personal belongings for doing business.

\section{B. Parking}

Parking is a place where the vehicle is stationary for a long time or cannot be determined depending on its needs and is also a means and infrastructure to support smooth traffic. Generally, parking facilities are provided outside of the street with the permission given. Law number 22 of 2009 states that parking facilities in road-owned spaces may only be provided in certain places which may be carried out by special parking or supporting business operations where diesel data is carried out in certain places such as district roads, village roads or city roads which are stated traffic signs or road markings.

Parking facilities consist of 2 types of parking in their placement, namely the on-street parking which is located on the side of the road, on the side of the road and in the parking area without parking controls and in off-street parking and parking areas to accommodate special a public place in the form of a building or parking park which is held for a special activity which becomes a supporting space for the main building activities.

\section{Spatial Activity}

Mangunwijaya [4] states that behavior-oriented architecture is a humane architecture, which is able to understand and accommodate human behavior captured from various kinds of behavior, be it the behavior of the creator, observer, and also the behavior of the surrounding nature. Based on this understanding, it can be seen that behavioral architecture is an approach that investigates the relationship between human behavior and residential areas that develop into business areas, of course, giving a new behavior outside of household activities, so that this new behavior causes additional space, especially the availability of parking in the Hbes business unit.

Behavior settings are physical or spatial elements that become a system of places or spaces as the creation of certain activities. One theory based on an ecological view is the behavior setting theory pioneered by Robert Barker and Alan Wicker [5]. This theory is an organism environment, namely the suitability of environmental design and the behavior that is accommodated in that environment [6]. Therefore, it is possible to have a structured behavior pattern called a 'program' which is linked to the setting of the place. This theory pays less attention to the psychological process of individual differences and emphasizes uniformity or collective behavior [7]. The relationship between humans and the environment is more explained in terms of social characteristics or characteristics such as habits, rules, typical activities, and physical characteristics [8].

Architecture and behavior have a close relationship when viewed through the aspects that shape human behavior due to the environment that is formed. Human behavior can direct architecture to be better and vice versa, that architecture can direct the behavior of the community to be better / worse.

\section{DATA AND ANALYSIS}

\section{A. Locus}

The main corridor of Penatih Village, Denpasar is a secondary collector road located in Penatih Village, East Denpasar. This corridor is $3.63 \mathrm{~km}$ long. Penatih Village has an area of $281 \mathrm{HA}$ with a total of 8 hamlets and 2 traditional villages. RDTR Denpasar City, Penatih Village 
has a residential area function. The Trengguli - Trenggana corridor is located in the village of Plagan, Penatih Village. According to the direction of the East Denpasar RDTR, the Trengguli Corridor is functioned as the center of agricultural and residential activities. The character of settlements in this corridor is the presence of traditional settlements on the left and right along the Trengguli Trenggana corridor.

The research area originated from a traditional settlement with the potential for regional development to become a mixed area, namely a residential function with a trade function. At this location, the theory of behavior architecture due to changes in corridor space is used, parking theory is able to identify the shape of the area by analyzing the relationship between building mass and outer space and the behavior formed in the main corridor of Penatih Village, East Denpasar. Another aspect that affects the development of this region is the economic aspect. The role of local government is also an influence in the changes that occur in this area.

The main corridor road of Penatih Kelurahan will be divided into 8 segments based on the criteria for the length of the corridor. The west side lane is a one-way circulation flow of vehicles from south to north, while the east side lane is a circulation from north to south. The division of segments or roads is divided based on the same characteristics in almost every road besides making it easier to analyze data.

\section{B. Number, Types and Management of Hbes in the Main Corridor Occupancy of Penatih Urban Village, East Denpasar}

Searching for the number, type and management of Hbes activities by conducting sequential surveys at each dwelling with 211 residential units that have more than one type of business and are run more than 1 family division, segments are divided into 8 segments starting from south to north. Selection as a sample is the Hbes activity that is on residential land and the community lives in the same location. There are $78.2 \%$ hbes that are managed privately, for hbes that are rented out is $12.8 \%$ and hbs that are managed privately and for rent is $9 \%$.

The most popular business activities in this corridor are stalls $29.38 \%$, followed by food stalls $16.59 \%$, shops / counters $26.06 \%$, refill water depots $1.43 \%$, workshops $4.73 \%$, salons $5.22 \%$, tailors $1.9 \%$, laundry $5.69 \%$, photocopy services $2.84 \%$ and others $6.1 \%$. The large number of business activities that are accommodated in this corridor has led to a large number of community members of activities that crowd the main corridor of Penatih Village, Denpasar, so that if visitors come to buy a product or service they will make a temporary stop which needs to be accommodated with a parking space in accordance with the provisions of Perda 5 of 2005 and Perwali 25 of 2010 concerning Requirements for Building Architecture in Denpasar City in order to create a beautiful, comfortable and safe environment.

$88 \%$ of the large part of the residential land that has been transformed into Hbes activities is telecommunications which is close to the road and only $11 \%$ changes to nonbooted space.

\section{Availability of Parking at Residential Activities with Home Based Enterprises in the Main Corridor of Penatih Village, East Denpasar}

Parking is an important space element in the design of a residential building or commercial function. The availability of available parking will indirectly affect the state of urban planning in a rural or urban area, while several case studies have been conducted to find out whether this building has provided parking to accommodate additional activities that occur. Changing the front land to accommodate business activities, adding a building to the rear of the residential area to rent boarding rooms so that in one location there are two functions of activity. The availability of parking to support business activities at this location is only provided no more than $8 \%$.

\section{Changes in Community Behavior that Occur in the Main Corridor of Penatih Village, Denpasar}

In the case study studied, more than $66.6 \%$ of the changes occurred in the telajak area, $22.2 \%$ occurred in the garage and $11.11 \%$ of the changes occurred in two places, namely telajak and bale dangin. Changes in space from occupancy to residence and business for residents who own land with access to main roads have an impact on changing their daily behavior. Changes in the behavior of the community in it where previously the civitas in the case study became more housewives with activities more often in the kitchen and at home but with the existence of their business function they often spent more time in their place of business.

The availability of business functions that develop without good planning in the main corridor of Penatih Subdistrict, Denpasar looks modest so that the tendency of the civitas behavior to pay less attention to and maintain the building or room used so that the appearance of the building is not uniform and does not look beautiful when viewed from the settlement pattern when viewed from access the road as traffic.

After the presence of Hbes, the survey results related to the use of road access in the main corridor of Penatih Ward, stated that pedestrians felt less safe and felt anxious when walking on the side of the road due to vehicles parked on the side of the road. Motorcyclists feel that after a lot of effort in the environment they feel heavy traffic flow, driving a vehicle must reduce speed and feel they must be vigilant if there is a vehicle parking space on the side of the road, feeling worried if a car driver opens the door.

Changes in behavior seen from respondents with 4wheelers felt that they had to stop more frequently and the traffic flow was not smooth because of the presence of other 4-wheeled vehicles parking on the side of the road. 
Journal of a Sustainable Global South, p-ISSN: 2579-6062

\section{CONCLUSION}

This research is intended to provide an overview of the phenomenon of business functions that develop sporadically in residential areas related to economic development. This study emphasizes the availability of parking for the land that will be added due to changes in behavior so that it is expected to be able to improve the quality of residential space in the area.

In addition, this research can be used as documentation of settlement development, one example of an illustration of the phenomenon of the use of residential land with business functions, for the city government to be able to reconsider the contribution of the informal economy which is an income for lower middle income residents so that planners are able to consider the prospect of the phenomenon while improving the impact that detrimental to urban space in order to achieve the integration of informal business opportunities with housing development while at the same time avoiding aesthetic changes.

\section{ACKNOWLEDGMENT}

The authors thank any parties that support this study, also to Udayana University.

\section{REFERENCES}

[1] Damawan, Edy. 2004. Teori Implementasi Perancangan Kota. Badan Penerbit Universitas Dipenogoro Semarang. Semarang

[2] Damawan, Edy. 2005. Analisa Ruang Publik Arsitektur Kota.. Badan Penerbit Universitas Dipenogoro Semarang. Semarang

[3] Haryadi, B. Setiawan. 1995. Arsitektur Lingkungan dan Perilaku. Dirjen Dikti Depdikbud. Jakarta

[4] Lawanson,Taibat \& Olanrewaju, David . 2012. Jurnal : The Home as Wokplace : Investigating Home Based Enterprises in Low Income Settlement of The Lagos Metropolis.

[5] Linch, Kevin. 1975. The Image of The City. The M.I.T Press. England.

[6] Eunice Smit \& Donaldson, Ronnie. Jurnal : The Home as Informal business location: Home - based Business (HBB) Dynamics in the medium - sized city of George.

[7] Turner, John F.C . 1976. Housing by People : Towards Autonomy in Building Environments. Pantheon Books. New York

[8] Nkeiru, Ezeadiche, 2012. Jurnal : Home - Based Enterprises in Urban Spaces: An Obligation for Strategic Planning? 